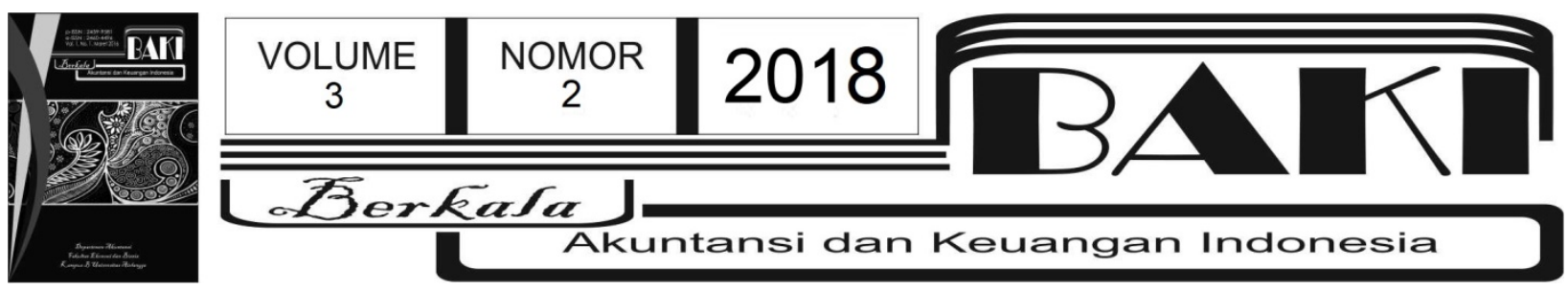

\title{
Inovasi Pelayanan: Telaah Literatur Perbandingan Sektor Privat dan Sektor Publik
}

\author{
Niluh Putu Dian Rosalina Handayani Narsa ${ }^{1}$ \\ ${ }^{1}$ Departemen Akuntansi, Fakultas Ekonomi dan Bisnis, Universitas Airlangga \\ niluh.narsa@feb.unair.ac.id
}

INFO ARTIKEL

Histori Artikel:

Tanggal Masuk 1 Oktober 2018

Tanggal Diterima 31 Oktober 2018

Tersedia Online 31 Desember 2018

Kata Kunci:

inovasi pelayanan; sektor

privat; sektor publik

\begin{abstract}
A B STRAK
Organisasi sektor publik memiliki beberapa karakteristik unik yang tidak dimiliki oleh organisasi sektor privat. Adanya perbedaan karakteristik tersebut akhirnya menyebabkan adanya perbedaan dalam hal-hal lain yang lebih spesifik. Salah satunya, secara tradisional dipandang bahwa perkembangan inovasi di sektor publik tidak terlalu pesat dibandingkan inovasi yang ada di sektor privat, padahal sektor publik sering menghadapi suatu tantangan yang lebih kompleks sehingga tentu dalam mengatasinya perlu upaya-upaya yang inovatif. Makalah ini bertujuan untuk mengetahui hambatan munculnya inovasi pada sektor publik melalui telaah perbedaan karakteristik inovasi di sektor publik dengan sektor privat, menelaah bagaimana inovasi pelayanan sektor publik di beberapa negara dan di Indonesia. Telaah dilengkapi dengan mengkaji atas riset-riset empiris yang telah dilakukan beberapa peneliti. Meski paper ini bersifat deskriptif dan non statistik, namun paper ini diharapkan dapat meningkatkan pemahaman mengenai inovasi di sektor publik.
\end{abstract}

\section{Pendahuluan}

Telah diketahui secara luas bahwa dibandingkan dengan organisasi sektor privat, organisasi sektor publik merupakan organisasi yang lebih tidak homogen dan kompleks (Halim dan Kusufi, 2013). Seperti yang dikatakan Mardiasmo (2006), akuntansi sektor publik memiliki kaitan erat pada domain publik yang wilayahnya lebih luas dan kompleks dibandingkan sektor privat atau bisnis. Keluasan wilayah publik tidak hanya disebabkan keluasan jenis dan bentuk organisasi yang berada di dalamnya, tetapi juga kompleksitas lingkungan yang mempengaruhi 
lembaga-lembaga publik tersebut. Selain kompleksitas, kekakuan dan ketidakflesibilitas yang ada di sektor publik juga menjadi pembeda utama.

Perbedaan sifat dan karakteristik sektor publik dengan sektor bisnis atau privat dapat dilihat melalui beberapa faktor. Mulai dari tujuan organisasi, sumber pembiayaan, pola pertanggungjawaban, struktur organisasi, karakteristik anggaran, stakeholder yang dipengaruhi, dan sistem akuntansi yang digunakan, serta tidak menutup kemungkinan faktor-faktor lainnya. (Mardiasmo 2009). Dari beberapa faktor tersebut, misal jika dilihat dari faktor pembeda struktur organisasi, sektor publik cenderung kaku, birokratis, statis, formal, dan hirarkis. Dengan kata lain sistem dalam sektor publik memiliki karakteristik status-quo dan jarang atau bahkan tidak menyukai perubahan. Banyak organisasi sektor publik merasa kurang tertantang karena berada dalam iklim yang tidak terlalu kompetitif. Hal tersebut kontras dengan karakteristik sektor privat yang mana ia cenderung fleksibel, datar, fungsional, dan dinamis (Suwarno 2008).

Adanya satu karakteristik yang kontras tersebut menyebabkan inovasi pada sektor privat lebih sering terjadi dibandingkan sektor publik. Inovasi dalam sebuah organisasi adalah salah satu hal krusial yang dapat menjamin keberlangsungan organisasi tersebut untuk bertahan hidup. Seirama, Moussa dkk. (2018) berpendapat bahwa inovasi merupakan salah satu topik yang tidak akan pernah habis dibahas dimanapun, karena ia memiliki dampak yang begitu signifikan bagi para pemimpin, komunitas, negara, dan bahkan bagi seluruh umat manusia.

Sebagai penentu mampu bersaing unggul atau tidak, inovasi menjadi konsep yang sering dibahas pada sektor bisnis. Dilihat dari level individu pun, pada umumnya pekerja yang terlibat di sektor publik hanya menjalankan tugas dan fungsinya secara datar-datar saja (Suwarno 2008). Seperti juga yang dikatakan oleh Delfgaauw (2008) bahwa pekerja di sektor publik memiliki reputasi yang tidak terlalu baik karena terkenal malas.

Menurut Suwarno (2008) setidaknya terdapat dua jenis inovasi yang sering dilakukan oleh sektor publik yaitu yang pertama terkait inovasi kebijakan dan yang kedua adalah inovasi pelayanan publik. Inovasi pelayanan seharusnya sering dilakukan oleh sektor publik karena sifat output yang dihasilkan oleh organisasi sektor publik umumnya tidak berbentuk produk fisik, tetapi berupa pelayanan (Halim dan Kusufi 2013). Oleh karenanya, seperti yang dikatakan Suwarno (2008), "sebuah kualitas pelayanan publik merupakan cerminan dari sebuah kualitas birokrasi pemerintah" yang mana merupakan hasil dari pergeseran paradigma mengenai pelayanan publik, hal tersebut menuntut adanya suatu inovasi dalam pemberian layanan publik sehingga inovasi pada sektor publik sebaik mungkin dapat dimaksimalkan pada segi pelayanannya (Suwarno 2008; UNDESA 2011 \& 2013). Misalnya, inovasi pelayanan publik yang saat ini sedang hangat-hangatnya dikembangkan di sektor publik di belahan dunia manapun adalah dalam hal information and technologies communities (ICT) (Suwarno 2008).

Kembali lagi pada fakta bahwa inovasi di sektor publik tidak sepesat yang terjadi di sektor privat, situasi tersebut bisa jadi tidak terlepas dari masih belum terjalannya dengan baik 
sistem reward dan punishment di sektor publik (Borins, 2001; Palmer, 2005; Koch dan Hauknes 2005; Suwarno 2008). Diketahui bahwa munculnya inovasi pada level organisasional maupun individual salah satunya juga berkaitan erat dengan sistem reward dan punishment (VigodaGadot 2003; Borins 2001). Menurut Suwarno (2008) faktor reward di sektor publik belum mencapai kriteria yang layak, pengukuran prestasi cenderung subjektif sehingga tidak mampu memotivasi individu untuk melakukan kinerja dengan lebih baik lagi hingga akhirnya belum mampu berinovasi.

Moussa dkk. (2018) berpendapat bahwa, kecilnya jumlah inovasi yang dilakukan pada sektor publik kemungkinan besar disebabkan karena masih terdapat sedikit pula pemahaman mengenai bagaimana sebenarnya inovasi di organisasi sektor publik berlangsung. Terlebih Golembiewski dan Vigoda (2000) dalam papernya menyatakan "inovasi yang sukses tidak akan dapat berkembang dalam model birokrasi tradisional". Pun dari segi literatur, penelitian dengan topik inovasi pada sektor publik masih sangat jarang dibahas oleh para peneliti. Senada, Bloch dan Bugge (2013) memiliki pendapat bahwa masih terdapat sedikit pemahaman mengenai apa itu inovasi di sektor publik, serta masih sedikit juga pemahaman tentang rerangka manajemen yang dapat memberikan penjelasan tentang bagaimana proses inovasi di organisasi sektor publik.

Berdasarkan pemaparan di atas, paper ini bertujuan untuk mengetahui faktor penyebab munculnya hambatan pada inovasi pada sektor publik melalui telaah perbedaan karakteristik inovasi di sektor publik dengan sektor privat, menelaah bagaimana inovasi pelayanan sektor publik di beberapa negara dan di Indonesia. Telaah dilengkapi dengan mengkaji atas riset-riset empiris yang telah dilakukan beberapa peneliti.

Meski paper ini adalah tulisan deskriptif dan berisfat nonstatistik, namun paper ini tetap penting karena paper ini akan memaparkan pemahaman mengenai hambatan apa yang muncul pada inovasi di sektor publik dan faktor-faktor yang diperlukan untuk mendorong inovasi di sektor publik. Sehingga dengan demikian, paper ini diharapkan dapat memberikan pemahaman mengenai isu-isu kritikal yang diperlukan untuk meningkatkan budaya inovasi pada sektor publik.

Bagian selanjutnya dari artikel ini akan membagi pembahasan menjadi tiga bab utama, yang mana masing-masing akan memiliki beberapa sub bahasan. Bab kedua akan membahas tinjauan literatur yang berisi mengenai pemaparan Inovasi Sektor Publik (terdiri dari dua sub bab). Lalu bab tiga akan membahas mengenai Bukti Empiris Faktor Penghambat dan Faktor Pendukung Inovasi di Sektor Publik. Selanjutnya bab keempat akan membahas mengenai contoh inovasi pelayanan sektor publik yang ada di beberapa negara serta juga membahas mengenai sistem reward dan punishment di Indonesia. Kemudian terakhir, Simpulan akan akan menjadi penutup dari akhir keseluruhan paper ini. 


\section{Tinjauan Pustaka}

\subsection{Inovasi: Definisi dan Konsepnya pada Sektor Publik}

Inovasi telah muncul dalam kosakata bahasa Inggris sejak abad ke-16. Kemudian pertama kali dikenalkan dalam Oxford English Dictionary di edisi tahun 1939 dengan definisi "the act of introducing a new product into market" (Suwarno, 2008). Berdasarkan Kamus Besar Bahasa Indonesia, inovasi adalah pemasukan atau pengenalan hal-hal yang baru; atau pembaharuan. Rogers dalam Suwarno (2008: 3), sebagai salah satu penulis buku terkemuka mengenai inovasi, menjelaskan bahwa inovasi adalah sebuah ide, praktek, atau objek yang dianggap baru oleh individu. Secara singkat Altschuler dan Zegans (1997) mendefinisikan inovasi sebagai "novelty in action", kemudian Mulgan dan Albury (2003) juga mendefinisikan inovasi secara singkat sebagai "new ideas that work". Sedangkan Kwaku (2012) mengatakan bahwa kunci penting sebuah inovasi adalah sejauh mana sesuatu tersebut memberikan solusi atas masalah yang penting.

Menurut Palmer (2005) definisi inovasi yang sesuai dalam sektor publik adalah "pengenalan disengaja dan penerapan dalam peran, kelompok atau organisasi ide, proses, produk atau prosedur, baru ke unit terkait adopsi, dirancang untuk secara signifikan menguntungkan kinerja peran, kelompok, atau masyarakat yang lebih luas". Definisi tersebut menawarkan perspektif yang luas tentang manfaat yang diharapkan, dibandingkan sektor privat.

Inovasi berbeda dengan kreativitas (Kwaku 2012; Suwarno 2008; Palmer, 2005). Kreativitas adalah bermimpi sedangkan inovasi adalah bangun dari kenyataan (Kwaku 2012). Menurut King (1990) dalam Palmer (2005) kreativitas adalah "bringing something new into existence" sedangkan menurut Mohr (1969) inovasi adalah "bringing something new into use".

Borins (2001) serta Borins (2000a, 2000b, 2001) mencari tau apa pendapat dari pekerjapekerja di sektor publik di Amerika mengenai inovasi dari progam-program yang telah mereka jalani. Jawaban atas hal tersebut menyediakan gambaran mengenai gambaran apa itu sebenarnya inovasi pada sektor publik menurut pekerja di sektor publik itu sendiri. Jawaban mereka umumnya adalah: (1) inovasi tergantung dari dalam organisasi, (2) inovasi melingkupi proses reengineering, (3) melibatkan penerapan teknologi informasi, (4) adanya pengembangan layanan alternatif, (4) adanya pemberdayaan karyawan. Gambaran-gambaran tersebut, secara singkat dirangkum oleh Torugsa dan Arundel (2016), yang berpendapat bahwa semakin kompleks inovasi, semakin besar jumlah hambatan yang harus dihadapi para perkerja untuk dapat mengimplementasikannya. Pada bagian selanjutnya dapat kita lihat alasan yang menyebabkan situasi di sektor publik lebih kompleks dibandingkan sektor privat. 
United Naiton's Department of Economic and Social Affairs (UNDESA) sejak tahun 2003 telah meluncurkan penghargaan United Nation's Public Service Awards yang mana intinya bertujuan untuk mendorong dan meningkatkan inovasi, peran, profesionalisme serta visibilitas dari pelayanan publik agar mereka lebih termotivasi lagi. Alasan keharusannya dilakukan inovasi pada sektor publik menurut UNDESA (2005) adalah: (1) demokratisasi, (2) perjanjian internasional, (3) terjadinya ketidakseimbangan penyebaran sumberdaya manusia unggulan, (4) birokrasi harus tertata lebih baik, (5) terjadinya privatisasi dan outsourcing di sektor publik.

Menurut UNDESA (2011) terkait inovasi, saat ini sektor publik menghadapi tiga tantangan utama, yaitu: (1) Pertama, sektor publik harus mampu beroperasi dan menyediakan kualitas layanan yang lebih tinggi dengan mengurangi sumber daya dan kapasitas yang terbatas. Artinya, pemerintah harus menggunakan sumber daya mereka dan membangun kapasitas yang tidak hanya lebih efektif tetapi juga lebih kreatif, dengan, misalnya, mendaftar dukungan dari sektor swasta dan masyarakat sipil dalam penyediaan layanan, (2) Kedua, mereka harus membuat lembaga-lembaga publik yang lebih akuntabel, responsif dan efektif., (3) Ketiga, dan yang paling penting, mereka harus merespon lebih memadai terhadap meningkatnya tuntutan masyarakat untuk lebih berpartisipasi dalam pembuatan kebijakan publik.

\subsection{Inovasi: Perbandingannya dengan Sektor Privat}

Hasil riset Borins (2001), yang meneliti tentang bagaimana inovasi pada organisasi sektor publik di beberapa negara di Amerika, mengatakan bahwa dalam hal pengembangan inovasi, kondisi yang ada di sektor publik kontras dengan yang ada di sektor privat. Hal tersebut disebabkan oleh beberapa faktor.

Pertama, seperti yang diketahui, bahwa struktur organisasional di sektor publik bersifat rigid, tidak fleksibel, serta lebih berkarakteristik status-quo sehingga mengakibatkan mereka cenderung tidak menyukai perubahan. Berbeda dengan kondisi yang ada di sektor privat dimana kondisinya adalah justru sebaliknya. Mereka dituntut untuk terus melakukan perubahan agar tidak tertinggal dari para kompetitornya (Suwarno 2008; Palmer 2005; Borins 2001).

Kedua, pada sektor privat terdapat apa yang disebut dengan venture capital, yaitu merupakan pihak yang memberikan modal, dengan kata lain venture capital dapat dikatakan sebagai sumber dari pendanaan. Termasuk juga salah satunya menyediakan dana untuk mengadakan program-program insentif untuk mendorong timbulnya inovasi.

Dalam sebuah perusahaan, pihak internal perusahaan atau yang sering diwakili dengan sebutan manajemen, memiliki tanggung jawab untuk mengelola perusahaan agar mampu memaksimalkan keuntungan dari para venture capital (investor). Agar mencapai kepentingan yang diinginkan pihak investor, kadang investor dengan sendirinya menyediakan dana berupa 
program-program insentif bagi para manajer perusahaan dengan harapan dapat mengembangkan ide-ide baru yang inovatif demi mencapai profit perusahaan yang maksimal. Burgess dan Metcalfe (1999) menunjukkan hasil secara empiris bahwa organisasi di sektor privat memanfaatkan dana yang ada jauh lebih banyak untuk dialokasikan sebagai beban insentif dibandingkan yang terjadi pada organisasi di sektor publik.

Situasi yang ada di sektor publik, seperti yang diistilahkan oleh Borins (2001) dan Suwarno (2008) adalah tradisional. Para pekerja di sektor publik dibayar dengan nilai gaji yang tetap. Jarang sekali dilakukan pemberian bonus atau hadiah. Sehingga meskipun pekerja di sektor publik melakukan sebuah inovasi dan itu ternyata berhasil, reward yang diberikan sedikit dan terbatas. Padahal insentif bermanfaat dalam mendorong atau memunculkan proses difusi (merembesnya) inovasi menjadi lebih berhasil (Suwarno 2008). Akibatnya mereka akan cenderung tidak melakukan invoasi.

Ketiga, adalah bahwa di sektor publik terjadi dengan apa yang disebut asymmetric incentives (Borins 2001). Asymmetric incentives adalah suatu kondisi dimana konsekuensi yang akan dihadapi jka sebuah inovasi gagal adalah sangat besar dibandingkan konsekuensi yang akan dihadapi jika sebuah inovasi berhasil.

Keempat, faktor lain yang juga penting adalah bahwa terdapat pengawasan yang berlebihan pada sektor publik. Media akan sangat mengekspos kegagalan yang dilakukan oleh sektor publik dan mengungkapkan kesalahan yang dilakukan oleh organisasi maupun pegawaipegawai sektor publik secara gamblang.

Dengan demikian, berdasarkan pemaparan di atas dapat disimpulkan bahwa perbedaan inovasi antara sektor privat dan sektor publik, yang mana inovasi lebih sering dilakukan di sektor privat, terdapat empat poin utama, yaitu:

1. Struktur organisasi: di sektor publik, struktur organisasionalnya adalah kaku dan tidak fleksibel sehingga ia akan cenderung untuk tidak menyukai perubahan berbeda dengan sektor privat yang dituntut untuk mampu terus melakukan perubahan agar tidak kalah dari para kompetitiornya.

2. Venture Capitalist: di sektor privat tidak ada venture capitalist, sedangkan sektor privat tersedia. Sehingga dana yang tersedia, misal untuk insentif (sistem reward) lebih banyak di sektor privat dibanding sektor publik.

3. Assymetric incentive: di sektor publik, terjadi apa yang disebut dengan assymetric incentive. Sedangkan di sektor privat tidak.

4. Pengawasan: di sektor publik, pengawasan lebih ketat. Sedikit saja melakukan kesalahan maka aka langsung diekspos secara besar-besaran. Tidak demikian di sektor privat.

Jika ingin ditelaah lebih lanjut, masih terdapat faktor-faktor lain penyebab terjadinya perbedaan dalam hal inovasi antara sektor privat dengan sektor publik. Hal tersebut dapat 
diketahui lewat pemerhatian pada perbedaan karakteristik sektor privat dengan sektor publik. Pada Tabel 1 telah disajikan secara ringkas perbedaannya berdasarkan delapan faktor pembeda selain empat faktor di atas. Berikut penjelasan singkat mengenai tambahan delapan faktor pembeda tersebut (sehingga total terdapat 12 faktor).

Tabel 2.1. (Lanjutan) Perbedaan Inovasi di Sektor Privat dengan Sektor Publik

\begin{tabular}{|c|c|c|c|c|}
\hline \multirow{2}{*}{ Keterangan } & \multicolumn{2}{|c|}{ Sektor Privat } & \multicolumn{2}{|c|}{ Sektor Publik } \\
\hline & Karakteristik & Faktor Inovasi & Karakteristik & Faktor Inovasi \\
\hline $\begin{array}{c}\text { Prinsip } \\
\text { Pengorganisasian }\end{array}$ & Mencari profit & Pasar & $\begin{array}{l}\text { Kebijakan } \\
\text { Publik }\end{array}$ & $\begin{array}{c}\text { Tekanan dan } \\
\text { kejadian politik }\end{array}$ \\
\hline Ukuran Kinerja & Kuantitatif & Mudah diukur & Kualitatif & Susah diukur \\
\hline Isu Manajemen & Autonomi & Taking a risk & $\begin{array}{l}\text { Tekanan } \\
\text { politik }\end{array}$ & $\begin{array}{l}\text { Disetujui lewat } \\
\text { proses politik }\end{array}$ \\
\hline $\begin{array}{c}\text { Hubungan } \\
\text { dengan pengguna } \\
\text { akhir }\end{array}$ & $\begin{array}{c}\text { Umpan balik } \\
\text { dari konsumen } \\
\text { (pasar) }\end{array}$ & $\begin{array}{c}\text { Terdapat } \\
\text { hubungan dengan } \\
\text { konsumen }\end{array}$ & Warganegara & $\begin{array}{c}\text { Tidak terbangun } \\
\text { hub. dengan } \\
\text { pelanggan }\end{array}$ \\
\hline Rantai penawaran & $\begin{array}{c}\text { Pemain besar } \\
\text { vs. kecil }\end{array}$ & $\begin{array}{c}\text { Menawarkan } \\
\text { inovasi } \\
\end{array}$ & $\begin{array}{l}\text { Tergantung } \\
\text { sektor privat }\end{array}$ & $\begin{array}{c}\text { Menentukan } \\
\text { standar }\end{array}$ \\
\hline $\begin{array}{c}\text { Sumber daya } \\
\text { manusia }\end{array}$ & $\begin{array}{c}\text { Motif } \\
\text { ekonomis }\end{array}$ & $\begin{array}{c}\text { Inovasi adalah } \\
\text { tuntutan }\end{array}$ & Motif idealisme & $\begin{array}{c}\text { Inovasi adalah } \\
\text { ancaman }\end{array}$ \\
\hline $\begin{array}{c}\text { Sumber } \\
\text { pengetahuan }\end{array}$ & Flexibel & Bervariasi & Rigid & Tetap \\
\hline Range waktu & $\begin{array}{c}\text { Jangka waktu } \\
\text { pendek }\end{array}$ & $\begin{array}{c}\text { Hasil lebih cepat } \\
\text { diketahui }\end{array}$ & $\begin{array}{c}\text { Jangka waktu } \\
\text { panjang }\end{array}$ & $\begin{array}{c}\text { Hasil lebih lama } \\
\text { diketahui }\end{array}$ \\
\hline
\end{tabular}

Sumber: diintisarikan dari Røste (2005).

5. Prinsip pengorganisasian: inovasi di sektor publik lebih didorong oleh siklus politik yang kemudian memunculkan kebijakan baru sedangkan di sektor privat lebih disebabkan karena dorongan pasar yang terus berubah.

6. Ukuran Kinerja: ukuran kinerja di sektor publik lebih susah untuk ditentukan berbeda dengan sektor privat. Terdapat beberapa faktor yang menjadi penyebab kesulitan dalam mengukur kinerja pada sektor publik. Akibatnya maka reward yang diberikan baik pada level organisasional, divisional, maupun individual pada sektor publik umumnya tidak berbasiskan pada moneter. Pada sektor privat, adalah hal yang biasa ketika reward yang diberikan berupa financial rewards, misal: insentif tunai, stock options. Hal tersebut berbeda dengan kondisi yang ada organisasi sektor publik. Umumnya reward yang diberikan adalah dalam bentuk penghargaan. Sekalipun reward yang diberikan adalah dalam bentuk finansial, jumlahnya akan sangat sedikit dan tidak akan sebanyak yang diberikan di sektor privat (Borins, 2001).

7. Isu Manajemen: di sektor publik, inovasi tidak dapat dilakukan tanpa adanya persetujuan politik sedangkan di sektor privat manajer justru diharuskan untuk berinovasi lewat proses pengambilan keputusan yang mengatasnamakan kepentingan investor.

8. Hubungan dengan pengguna akhir: pengguna akhir di sektor publik adalah masyarakat secara luas sehingga hubungan dengan mereka sebagai end-users susah untuk terjalin 
dengan baik akibatnya inovasi tidak terlalu didorong oleh faktor dari end-users. Berbeda dengan sektor privat dimana end-users sangat krusial dan berperan dalam mendorong munculnya inovasi.

9. Rantai Supply: dalam hal pengadaan barang dan jasa, sektor publik bergantung pada sektor privat dimana dalam hal tersebut seringnya standar ditentukan oleh sektor publik sedangkan tawaran inovasi datang dari sektor privat.

10. SDM: pegawai di sektor publik bekerja atas dasar idealisme sehingga sering melihat inovasi adalah bentuk ancaman berbeda dengan pekerja di sektor privat bekerja atas dasar motif ekonomi.

11. Sumber pengetahuan: pemanfaatan pengetahuan di sektor publik agak kaku karena terhambat prosedur sehingga tidak punya banyak pilihan. Sektor privat tidak demikian sehingga punya banyak pilihan dan inovasinya bervariasi.

12. Range waktu: pekerjaan di sektor publik biasanya memakan waktu lebih lama sehingga sulit untuk mengidentifikasi sebuah inovasi telah berhasil atau gagal. Sektor privat bekerja dalam waktu lebih singkat karena motif utama mengejar kepentingan keuntungan.

Oleh karena munculnya beberapa faktor-faktor pembeda tersebut, menyebabkan inovasi yang muncul dari sektor privat dan sektor publik menjadi berbeda baik dalam hal proses maupun produknya. Sebenarnya istilah produk lebih banyak dikenal di sektor privat. Namun jika dilihat dari perspektif pemasaran, istilah produk dapat diartikan secara lebih luas (Kotler dan Keller 2009).

Tabel 2.2. Contoh Tipe Produk di Sektor Privat dan Publik

\begin{tabular}{lll}
\multicolumn{1}{c}{ Tipe Produk } & \multicolumn{1}{c}{ Sektor Publik } & \multicolumn{1}{c}{ Sektor Privat } \\
Barang fisik & Paspor, KTP, SIM & Handphone, TV \\
Jasa & Pelayanan Pajak & Salon Rambut \\
Event & Perayaan 17 Agustus & Siaran liga Champions \\
Tempat & Taman Nasional & Ciputra Waterpark \\
Organisasi & Badan Pusat Statistik & Microsoft \\
Informasi & Daftar Pencarian Orang & Headline News Metro TV \\
Ide & Pelatihan & Asuransi Pensiunan \\
\hline Diadaptasi dari: Kotler (2010) &
\end{tabular}

Diketahui bahwa jenis produk yang dihasilkan oleh sektor publik nantinya lebih bertujuan untuk banyak orang (masyarakat yang lebih luas). Dalam praktiknya, sektor publik berinovasi bukan bertujuan untuk bertahan hidup (survive) melainkan untuk menjaga kepentingan publik dengan memberikan output berupa pelayanan publik (Suwarno 2008). Namun demikian menurut Suwarno (2008) pada praktiknya akhirnya sektor privat dan sektor publik akan membaur sehingga tercipta situasi yang saling melengkapi, istilah familiar atas hal tersebut adalah Public-private Partnership. Hal tersebut sejalan dengan akibat dari adanya pergeseran prinsip pelayanan publik yang akan dijelaskan pada bagian berikutnya. 


\section{Pembahasan: Bukti Empiris Faktor Penghambat dan Faktor Pendorong Inovasi di Sektor Publik}

Penelitian dengan tema inovasi di sektor publik mayoritas lebih menekankan pada alasan mengapa harus ada inovasi atau perubahan pada sektor publik serta bagaimana perubahan tersebut seharusnya dilakukan. Namun demikian masih sedikit yang membahas bagaimana mendorong seluruh sistem untuk memiliki kapasitas inovasi yang lebih besar (Moussa dkk., 2018). Untuk bisa menjawab pertanyaan tersebut, maka para akademisi sebaiknya terlebih dahulu mengisi gap penelitian yang ada dengan melakukan penelitian yang mencoba menganalisis faktor-faktor yang menyebabkan terhambatnya inovasi di sektor publik serta sebaliknya, faktor-faktor apa yang bisa mendorong inovasi di sektor publik. Bagian ini akan memaparkan secara singkat temuan-temuan empiris dari para peneliti mengenai hal tersebut.

Penelitian yang dilakukan di Organisasi Sektor Publik yang ada di India oleh Manimala dkk. (2006), merangkum banyak sekali temuan atas faktor-faktor yang menghambat inovasi disana, di antaranya adalah: kurangnya dukungan dari atasan langsung, sistem yang tidak mendukung dalam pengelolaan ide, fasilitas yang buruk, sedikitnya penekanan pada diseminasi dan komersialisasi, sistem penghargaan dan insentif yang itdak memadai, prosedur yang kaku dan tidak efisien, persepsi yang buruk dari proses manajemen perubahan, strategi yang ambigu, terlalu banyak pembentukan tim-tim informal, serta yang juga penting adalah kurangnya kemampuan personil dalam menyelesaikan masalah kompleks.

Senada, dalam tulisannya mengenai pengelolaan kolaborasi administrasi publik, VigodaGadot (2003) menuliskan bahwa hal-hal seperti sistem reward yang buruk, isu-isu yang tidak terselesaikan pada proses perencanaan dan penganggaran, pergeseran budaya, kompetensi yang masih belum memadai dalam hal manajemen risiko dan manajemen perubahan oleh para petugas di sektor publik merupakan penyebab utama kegagalan inovasi di sektor publik.

Di UK, Mulgan dan Albury (2003) melakukan pengidentfikasian faktor-faktor penghalang potensial yang dapat menghalangi proses inovasi di pelayanan publik disana. Pertama, mereka menemukan bahwa terdapat tekanan yang dirasakan pada layanan pengiriman karena persepsi dari petugas di bagian tersebut yang berpikir bahwa merkea tidak memiliki waktu yang cukup untuk mencoba mengupayakan cara lain yang bebeda dalam proses pengiriman yang lebih efektif dan lebih baik dari proses yang sekarang. Kedua, titdak terdapat sistem penghargaan dan insentif yang diatur dengan baik. Sistem penghargaan dan insentif telah sejak lama diabaikan. Ketiga, para individu seringkali menolak untuk melakukan perubahan terutama ketika dikenalkan dengan teknologi dan budaya yang baru.

Dengan mengetahui faktor-faktor penghambat tersebut, maka sebenarnya secara logis kita dapat menyimpulkan faktor-faktor pendorongnya - yaitu faktor-faktor yang bersifat sebaliknya. Beberapa peneliti juga telah menganalisis faktor-faktor yang dapat mendorong 
inovasi di sektor publik. Diakui bahwa sampai detik ini, seorang pemimpin (leader) dianggap masih merupakan faktor yang paling krusial dalam meningkatkan inovasi dan kreativitas (Burns dan Salker 1961; Muenjohn dan McMurray 2016). Pemimpin inovatif merupakan seseroang yang mampu mempengaruhi dan menstimulasi individu lain untuk bekerja secara kolaboratif untuk mencapai hasil yang signifikan, selain itu mereka juga merupakan seseorang yang mampu memahami karakteristik dan nilai-nilai etis yang dipegang oleh bawahannya sehingga dapat meningkatkan produktivitas dan komitmen mereka (Muenjohn dan McMurray 2016). Beberapa bukti empiris yang mendukung hal tersebut di antaranya adalah, pertama, survey yang dilakukan oleh Yoshida dkk. (2014) di Cina dan Indonesia ditemukan bukti bahwa pemimpin yang berfilosifi melayani (servant leaderhsip), ternyata mampu meningkatkan kreativitas karyawan dan invoasi tim. Sebaliknya, di Amerika dan Jepang, Osborn dan Marion (2009) menemukan bahwa pencapaian inovasi yang rendah justru terjadi ketika kepemimpinan dalam organisasi bersifat transformasional, berbeda dengan yang ada di Jerman, Engelen dkk (2014) justru menemukan bahwa di bawah kepemimpinan transformasional, karyawan justru menunjukkan kreativitas yang lebih. Dapat disimpulkan, apapun itu jenis kepemimpinannya, seorang pemimpin menjadi kunci utama inovasi pada sebuah organisasi.

Faktor lain sistem penghargaan dan insentif bisa dikatakan merupakan faktor paling penting (Bland dkk., 2010). Dengan menyadari bahwa inovasi merupakan proses yang dinamis dan bersifat berulang-ulang, dalam penelitiannya yang bersifat eksploratif, Bland dkk. (2010) menemukan bahwa mekanisme network-innovation perlu dipertimbangkan dengan baik ketika akan memasukkan unsur insentif di dalamnya karena berkaitan dengan bagaimana data, informasi, dan pengetahuan dialirkan dan dianalisis. Selain itu Delfgaauw dan Dur (2008) dalam penelitiannya menemukan bahwa ketika usaha dan pekerjaan pegawai sektor publik tidak perlu diverifikasi- yang mana nantinya akan dikaitkan dengan insentif masing-masing, para pegawai yang malas justru lebih tertarik bekerja di sektor publik.

Masih berkaitan dengan sistem penghargaan dan insentif, penelitian selanjutnya dapat memperoleh bukti empiris yang lebih bermakna lewat digunakannya metoda eksperimental seperti yang disarankan oleh Potts dan Kastelle (2010). Dalam tulisannya mengenai perspektif ekonomi dari insentif untuk mendorong inovasi di sektor publik, metoda eksperimental merupakan pendekatan terbaik untuk menguji sebuah hubungan kausalitas namun masih tidak banyak disadari oleh banyak peneliti terutama pada literatur inovasi sektor publik.

Dari segi sumberdaya manusia, hal-hal yang dapat dilakukan untuk mendorong para pekerja di sektor publik agar dapat meningkatkan kemampuannya dalam berinovasi menurut Torugsa dan Arundel (2016) adalah dengan cara: 1) mengembangkan kompetensi manajemen; 2) mengatasi hambatan dengan lebih mempelajari hal-hal yang memicu inovasi, bukan menghindarinya; 3) mengembangkan kondisi yang dapat memotivasi seluruh individu di organisasi untuk melakukan inovasi. Dengan demikian dapat disimpulkan bahwa, untuk 
mendorong agar pekerja di sektor publik turut berpartisipasi dalam inovasi, maka membangun budaya organisasi merupakan hal yang penting.

Membangun budaya inovasi pada suatu organisasi dapat dimulai dengan menciptakan iklim organisasi yang baik, seperti kondisi fisik bangunan yang memadai, kondisi psycho-social yang memadai, serta diterapkannya praktik-praktik baik (work wellbeing practice) secara konsisten seperti knowledge sharing. Meski demikian, perubahan iklim organisasi saja tidak cukup karena iklim organisasi hanya terbatas pada level grup, berbeda dengan budaya organisasi yang sudah berasosiasi dengan level departemen dan organisasi (Bamel dkk. 2013). Oleh karenanya sikap resistance to change yang muncul dari setiap pekerja merupakan faktor hambatan dasar bagi organisasi untuk melakukan inovasi.

Tabel 3.1. Faktor Penghambat dan Pendorong Inovasi di Sektor Publik

\begin{tabular}{|c|c|c|}
\hline \multirow[b]{2}{*}{ Faktor Penghambat } & \multicolumn{2}{|c|}{ Faktor Pendorong } \\
\hline & Karakteristik Kepemimpinan & $\begin{array}{c}\text { Isu Budaya dan Iklim } \\
\text { Organisasi }\end{array}$ \\
\hline $\begin{array}{l}\text { - Perbedaan budaya } \\
\text { - Model organisasi yang sudah } \\
\text { usang (komunikasi satu arah, } \\
\text { birokrasi yang kompleks) } \\
\text { - Jarang dilakukannya } \\
\text { pelatihan dan pendampingan } \\
\text { - Kurangnya keahlian } \\
\text { sumberdaya manusia dalam } \\
\text { hal pemecahan masalah, } \\
\text { dialog antar tim, manajemen } \\
\text { konflik } \\
\text { - Sistem insentif dan } \\
\text { punishment yang belum } \\
\text { memadai } \\
\text { - Isu ketidakpercayaan, } \\
\text { resistance to change }\end{array}$ & $\begin{array}{l}\text { - Selalu mendukung, } \\
\text { menginspirasi, menghargai dan } \\
\text { mempercayai bawahan } \\
\text { - Optimistik, realistik, persisten, } \\
\text { netral (tidak memihak), peka } \\
\text { dan penuh perhatian } \\
\text { - Menjunjung integritas dan } \\
\text { kejujuran } \\
\text { - Baik dalam pengambilan } \\
\text { keputusan pemecahan } \\
\text { masalah, pemikiran ke depan } \\
\text { (strategis) } \\
\text { - Kehati-hatian, keberanian, } \\
\text { ketegasan } \\
\text { - Komunikasi yang efektif dan } \\
\text { persuasif }\end{array}$ & $\begin{array}{l}\text { - Kondisi fisik dan eksposure } \\
\text { yang baik } \\
\text { - Kondisi psycho-sosial yang } \\
\text { baik } \\
\text { - Diterapkannya praktik- } \\
\text { praktik bekerja yang baik } \\
\text { secara konsisten (misal } \\
\text { knowledge sharing) }\end{array}$ \\
\hline
\end{tabular}

Sumber: disadur dari Moussa dkk. (2018)

\section{Pembahasan: Contoh Inovasi Pelayanan Sektor Publik di Beberapa Negara}

Satu tantangan utama bagi para praktisi di sektor publik, adalah bagaimana mengembangkan sistem, proses, dan iklim yang dapat meningkatkan dan mempromosikan invoasi dan kreativitas (Moussa dkk. 2018). Akibat dari tantangan yang muncul bagi organisasi sektor publik - seperti yang diungkapkan oleh UNDESA - akhirnya menyebabkan beberapa negara di seluruh dunia sedang berusaha untuk merevitalisasi sektor publik mereka dan membuatnya lebih proaktif, lebih efisien, lebih akuntabel serta terutama lebih berorientasi layanan. Untuk mencapai transformasi ini, pemerintah memperkenalkan inovasi dalam mereka struktur organisasi, praktik, kapasitas dan metode, serta menggunakan segala macam sumber daya manusia, material, informasi, teknologi dan keuangan untuk memberikan pelayanan yang 
lebih baik (Moussa dkk., 2018). Berikut akan dipaparkan mengenai latar belakang pentingnya inovasi pada pelayanan sektor publik.

Fungsi pelayanan publik merupakan salah satu fungsi dasar yang harus dikelola oleh pemerintah, entah itu dalam tingkat pusat maupun daerah (Suwarno 2008). Pelayanan publik, menurut Undang-undang Nomor 25 Tahun 2009, adalah kegiatan atau rangkaian kegiatan dalam rangka pemenuhan keutuhan pelayanan dalam rangka pemenuhan kebutuhan pelayanan sesuai dengan peraturan perundang-undagnan bagi setiap warga negara dan penduduk atas barang, jasa, dan/atau pelayanan administratif yang disediakan oleh penyelenggara pelayanan publik.

Inovasi yang dilakukan di sektor publik - khususnya dalam hal pelayanan - tentu saja fungsi utamanya adalah untuk meningkatkan kualitas pelayanan publik. Dalam rangka mencapai kualitas pelayanan yang baik diperlukan sebuah standar pelayanan publik yang kemudian menjadi tolak ukur dalam pelayanan yang berkualitas (Suwarno 2008). Menurut Albrecht dan Zemke (1990) dalam Sancoko (2010) dikatakan bahwa kualitas pelayanan publik merupakan hasil interaksi dari empat hal, yaitu: (1) sistem yang dibangun organisasi penyedia pelayanan, (2) sumberdaya manusia pemberi pelayanan, (3) strategi pelayanan, serta (4) pelanggan atau pengguna layanan.

Sejak terjadi reformasi di sektor publik pada tahun 1990-an, paradigma pelayanan publik telah bergeser dari prinsip "rowing" - yakni dimana kualitas birokrasi pemerintah merupakan cerminan dari kualitas pelayanan publik. Sehingga peran pemerintah sangat besar dalam pelayanan sektor publik dan pihak di luar itu (seperti masyarakat dan sektor swasta) tidak memperoleh kesempatan untuk mengaturnya. Namun sekarang paradigma baru dari pelayanan di sektor publik adalah "steering" - yakni prinsip dimana pemerintah tidak lagi bertindak sebagai pengayuh sendirian. Artinya bahwa pihak di luar pemerintah bisa bekerja sama dengan pemerintah karena bisa saja suatu hal akan lebih efisien dan efektif apabila hal tersebut dikerjakan oleh pihak di luar pemerintahan (Suwarno 2008). Contoh nyata atas hal tersebut adalah adanya privatisasi pada perusahaan-perusahaan milik negara serta public-private partnersip. Selain itu, fungsi pelayanan publik yang bergeser paradigmanya tersebut, pada akhirnya menempatkan masyarakat bukan lagi sebagai kelompok yang pasif. Masyarakat harus turut pula berpartisipasi dalam proses peningkatan pelayanan publik.

Menurut Mardiasmo (2009) serta Nurcholis (2005), fungsi pelayanan publik dapat dibagi dalam beberapa bidang. Contohnya seperti: pendidikan, kesehatan, keagamaan, lingkungan, rekreasi, sosial, perumahan, air minum, energi dan listrik, jalan tol, transportasi.

Sejak tahun 2003, UNDESA rutin menilai bagaimana inovasi dari beberapa organisasi sektor publik yang ada di beberapa negara, menilainya, lalu kemudian mengkompilasikannya dalam sebuah buku yang berjudul Compendium of Best Practices and Innovations in Public Administration. Seiring berjalannya waktu, dengan semakin berkembangnya informasi dan 
teknologi maka inovasi dalam organisasi sektor publik telah mengerucut dan mengarah ke satu hal, yakni dilakukannya penerapan basis elektronik (seperti E-Government). Sehingga sejak tahun 2011 isu inovasi dalam sektor publik adalah lebih ke arah diterapkannya ICT (Information and communication technology). Berikut akan disajikan contoh inovasi pelayanan publik yang telah dilakukan di beberapa negara dan juga Indonesia dalam kurun waktu empat waktu terakhir.

\subsection{Contoh Inovasi Pelayanan Sektor Publik: India, Nigeria, dan Singapura}

India di tahun 2012, terbilang masih sangat lamban dalam mengatasi kematian ibu dan anak. Solusi yang dikeluarkan oleh District Health Society Uttar Pradesh adalah "Aarogyam". Aarogyam dibentuk untuk menyediakan dari door to door dan teknologi berbasis kesehatan yang memiliki fokus pada ibu dan anak untuk mempromosikan penyediaan layanan yang dapat diakses semua pihak dan merata Kemudian di tahun 2013 India melakukan inovasi pelayanan publik dengan nama "Swavalamban" yang mana menciptakan direct cast transfer ke dalam rekening pensiunan sebelum bulan ketujuh. Inovasi tersebut dilakukan karena adanya problem terkait proses pencairan dana dalam pembayaran pensiun, pendaftaran baru penisunan ternyata sangat rumit dan membutuhkan banyak kertas-kertas sehingga tidak efisien.

Nigeria, sebagai negara berkembang, di tahun 2013 melakukan dua inovasi pelayanan publik. Pemerintah Nigeria telah menghabiskan $\$ 120$ juta pada proyek infrastruktur ICT untuk membangun 1-GOV yakni peranti lunak bagi pemerintah yang mana menawarkan pelayanan kepada seluruh pemerintah Nigeria. Perangkat ini dapat membantu dan memberikan konstribusi dalam pelayanan perbaikan secara keseluruhan sebagai contoh otomatisasi gaji dan perbaikan dalam proses penerbitan surat izin untuk pengemudi oleh federal komisi keselamatan jalan. Selain itu pemerintah Nigeria juga membangun Mobile Integrated Primary Health Care Service Delivery "MAILAFIYA" yang memberikan akses kepada 74\% warga Nigeria pedesaan dan miskin - khususnya di daerah terpencil - terhadap layanan kesehatan keliling secara cuma-cuma.

Satu contoh negara lagi, yaitu negara yang lokasinya sangat berdekatan dengan Indonesia - namun ia lebih maju dibandingkan Indonesia - yakni Singapura. Pada tahun 2012, Singapura mengadakan "Promoting Accountability for Procurement of Public Projects" dengan basis online. Proyek tersebut adalah terkait kegiatan pengadaan prasarana dan pembangunan sektor publik (seperti kegiatan konstruksi). Dengan adanya proyek ini, seluruh instansi pemerintah dengan sangat mudah memilih kontraktor yang terlah terdaftar melalui sistem yang sebelumnya prosedurnya dilalui secara manual. Hal positif yang didapat adalah biaya menjadi terpangkas serta transparasi meningkat. Karena kesempatan kontraktor untuk berkonspirasi dengan petuas untuk memenangkan tender dapat diminimalkan. 


\subsection{Inovasi Pelayanan Publik di Indonesia}

Di Indonesia, sama seperti dengan negara lainnya, pelayanan publik memiliki peran penting dalam kehidupan ekonomi, politik, serta peningkatan kualitas hidup sosial (Sancoko, 2010). Kesadaran atas pentingnya inovasi teknologi informasi dalam penyelenggaraan pelayanan publik sudah dirasakan sejak awal. Hal tersebut terlihat - contohnya - dengan semakin banyaknya lembaga pemerintah maupun organisasi publik yang berlomba-lomba untuk meluncurkan situs pelayanan. Namun, seperti yang disampaikan Suwarno (2008), kebanyakan situs-situs web pelayanan tersebut tidak bersifat interaktif.

Pada tahun 2014 lalu, Pemerintah - lewat kompetisi yang diselenggarakan Kementrian Pendayagunaan Aparatur Negara dan Reformasi Birokrasi - menetapkan sembilan inovator pelayanan publik terbaik di Indonesia, baik pada kementrian, lembaga, maupun pemerintah daerah. Dari kesembilan inovasi tersebut, hanya tiga yang berhubungan dengan sistem berbasis elektronik (Santoso 2014).

Pertama adalah Ditjen Administrasi Hukum Umum melakukan inovasi berupa aplikasi fidusia online. Masyarakat dapat mengakses dimana dan kapan saja sehingga efektif memangkas biaya dan waktu yang diperlukan dalam pembuatan fidusia secara manual. Kemudian yang kedua adalah Provinsi jawa Barat, pemerintah di provinsi Jawa Barat membuat sebuah aplikasi dimana para pengambil kebijakan khususnya di level pemerintah daerah dapat dengan segera mengakses informasi mengenai data rumah tangga miskin di suatu wilayah. Sehingga diharapkan dapat kebijakan yang diambil akan tepat sasaran, cepat, dan tidak lagi menimbulkan berbagai permasalahan sosial.

Selanjutnya, Pemkot Surabaya membuat dua produk penerapan teknologi inormasi, yang pertama adalah Surabaya Single Window. Merupakan sistem yang memungkinkan dilakukannya suatu penyampaian data dan informasi serta pemrosesannya secara tunggal dan sinkron sehingga sesuai dengan tugas dan fungsi masing-masing SKPD dalam hal pelayanan perizinan dan non perizinan. Produk kedua adalah Government Resources Management System. Merupakan sisem pengelolaan sumber daya pemerintahan berbasis web dan dapat diakses melalui media internet yang terintegrasi dari aktivitas birokrasi hulu sampai hilir (dalam konteks belanja). Sistem tersebut dibuat dengan tujuan salah satunya adalah mencegah korupsi dalam birokrasi.

Menurut Suwarno (2008) terdapat setidaknya lima alasan mengapa masih jarang dilakukannya inovasi layanan sektor publik yang berkaitan dengan sistem berbasis elektronik (ICT). Pertama, masalah trust dan legitimasi. Banyak orang Indonesia masih percaya terhadap sistem yang manual, contohnya saja penghitungan suara oleh KPU. Dasar penghitungan secara online yang lebih cepat dan up-to-date justru tidak diakui. Kedua, masalah willingness. 
Para pengambil keputusan sering tidak sepakat dan tidak mendukung, karena lagi-lagi sistem secara manual lebih dianggap. Ketiga, masalah infrastruktur. Tidak dapat dipungkiri bahwa infrastruktur di Indonesia masih jauh dari memadai. Keempat, masalah literasi dan gagap teknologi. Masyarakat Indonesia mayoritas belum terbiasa benar dengan segala sesuatu yang bersifat online karena tingkat pendidikan mereka pun rata-rata tidak tinggi. Terakhir, adalah masalah akses dan daya beli. Di negara berkembang, permasalahan biaya akses seringkali tidak seimbang dengan masih rendahnya daya beli masyarakat. Terlepas dari beberapa contoh yang telah disebutkan pada paper ini mengenai inovasi yang ada di Indonesia, sebenarnya masih cukup banyak contoh-contoh lain, namun demikian bukan fokus paper ini untuk membahas hal tersebut.

\section{Kesimpulan, Keterbatasan, dan Saran}

Karakteristik pada sektor publik yang berbeda dengan sektor privat akhirnya menyebabkan timbulnya perbedaan pula pada hal-hal spesifik lainnya. Terdapat beberapa faktor pembeda yang menjadi pengambat atas terjadinya inovasi pada sektor publik, yang mana setelah ditelaah terdapat 12 faktor dan juga belum termasuk bukti empiris dari beberapa peneliti terkait faktor penghambat dan pendorong inovasi di sektor publik yang telah dijelaskan pula pada bagian ketiga.

Seiring berjalannya waktu, terlebih dengan semakin berkembangnya informasi dan teknologi, menyebabkan inovasi pada sektor publik telah mengerucut dan mengarah ke satu hal, yakni dilakukannya penerapan basis elektronik. Sehingga sejak tahun 2011 isu inovasi dalam sektor publik adalah lebih ke arah diterapkannya ICT (Information and communication technology). Di hampir seluruh sektor publik di dunia, saat ini tengah berlomba-lomba untuk mampu menciptakan sebuah inovasi dalam hal pemanfaatan sistem teknologi informasi karena dengan begitu keseluruhannya dapat terkelola dengan lebih efektif, efisien, akuntabel, dan terukur. Namun di Indonesia sendiri, hal tersebut masih jarang dilakukan karena adanya beberapa faktor.

Tulisan ini tidak lepas dari keterbatasan, pertama adalah sifatnya yang masih berupa deskriptif dan tidak mencoba untuk menggali hubungan yang mungkin muncul terkait inovasi di sektor publik, oleh karenanya penelitian selanjutnya dapat mengkaji secara korelasional atas faktor-faktor penghambat dan pendorong inovasi di sektor publik. Penggunaan metoda eksperimental juga dianggap sangat menarik terutama untuk mengkaji sejauh mana reward, insentif dan punishment berperan dalam inovasi di sektor publik. Kelemahan utama lainnya adalah tentu saja contoh-contoh inovasi yang ditampilkan pada tulisan ini masih secuil dari banyaknya inovasi sektor publik yang telah dilakukan. 


\section{Daftar Pustaka}

Altschuler, A. and M. Zegans. 1997, Innovation and public management: Notes from the state house and city hall. In Altchuler, A. and Behn, R. (Eds), Innovation in American Government

Bamel, U.K., P. Budhwar., \& N. Bamel. 2013. "Revisiting Organisational Climate: Conceptualization, Interpretation and Application". Paper Presented to $3^{\text {rd }}$ Biennial Conference of the Indian Academy of Management (IAM), Indian Institute of Management, Ahmedabad (IIMA), 12-14 December, 2013.

Bland, T., B. Bruk, D. Kim, K.T. Lee. 2010. Enhancing Public Sector InnovationL Examining the Network-Innovation Relationshop. The Innovation Journal: The Public Sector Innovation Journal 15 (3): 1-17.

Bloch, C., \& M. Bugge. 2013. "Public Sector Innovation: From Theory to Measurement". Structural Change and Economic Dynamics 27 (null): 33-145.

Borins, Sandford. 2000a. What border? Public management innovation in the United States and Canada. Public Administration Review 60 (6): 490-499.

2000b. Public Service Awards Programs: An Exploratory Analysis. Canadian Public Administration 43 (3): 321-342.

2001. Encouraging Innovation in the Public Sector. Journal of Intellectual Capital 2 (3): 310-319.

Burgess, S. dan P. Metcalfe. 1999. The Use of Incentive Schemes in the Public and Private Sectors: Evidence from British Establishments. CMPO Paper Series, No. 00/15.

Burns, T., dan G. M. Stalker. 1961. The Management of Innovation. Tavistock, London.

Delfgaauw, J., dan R. Dur. 2008. Incentives and Workers' Motivation in the Public Sector. The Economic Journal 118 (525): 171-191.

Desvaliana, J. W. 2012. Pengaruh Remunerasi dengan Tingkat Employee Engagement. Unpublished Master Thesis. Universitas Indonesia, Jakarta, Indonesia.

Engelen, A., S. Schmidt, L.Strenger, dan M. Brettel. 2014. "Top Management's Transformational Leader Behaviours and Innovation Orientation: A Cross-Cultural Perspective in Eight Countries". Journal of international Management 20 (2): 124-136.

Golembiewski, R.T., dan E. Vigoda. 2000. "Organizational Innovation and the Science/Craft of Management" in Rahim, M.A., Golembiewski, R.T, \& Mackenzie, K.D., eds., Current Topics in Management, Vol. 5. Greenwich, Conn.: JAI Press.

Halim, A., dan S. Kusufi. 2013. Teori, Konsep, dan Aplikasi Akuntansi Sektor Publik. Jakarta: Salemba Empat.

Koch, P., dan J. Hauknes. 2005. On Innovation in the Public Sector - Today and Beyond. PUBLIN Project on Innovation in the Public Sector, Report no. D20, Oslo: Nifu Step

Kotler, P., \& K. L. Keller. 2009. Manajemen Pemasaran. Jakarta: Erlangga

Kwaku, A. G. 2012. What is Innovation?. African Business 390: 66-67.

Manimala, M.J., P.D. Jose, P.D., dan K. R. Thomas. 2006. "Organizational Constraints on Innovation and Intrapreneurship: Insights from Public Sector". The Journal for Decision Makers 31 (1): pp. 49-60.

Mardiasmo. 2006. Pewujudan Transparasi dan Akuntabilitas Publik Melalui Akuntansi Sektor Publik: Suatu Sarana Good Governance. Jurnal Akuntansi Pemerintah 2 (1): 1-17. 
Moussa, M., A. McMurray, dan N. Muenjohn. 2018. A Conceptual Framework of the Factors Influencing Innovation in Public Sector Organizations. The Journal of Developing Areas 52 (3): 231-242.

Muenjohn, N., dan A. McMurray. 2014. "The Conceptual Relationship between Work Values Ethics, Innovation and Leadership". The Asian Conference on Business \& Public Policy, 2014. Official Conference Proceedings, pp. 43-50. The International Academic Forum (IAFOR).

Mulgan, G. dan D. Albury. 2003, Innovations in the Public Sector (Cabinet Office, London).

Osborn, R.N., dan R. Marion. 2009. "Contextual Leadership, Transformational Leadership and the Performance of International Innovation Seeking Alliances". The Leadership Quarterly 20 (2): 191-206.

Palmer, J. W. 2005. Innovative Behavior of Frontline Employees in the Public Sector. Unpublished doctoral dissertation. University of Cincinnati, Ohio, United States.

Pemerintah Republik Indonesia. 2009. Undang-undang Republik Indonesia Nomor 25 Tahun 2009 tentang Pelayanan Publik. Jakarta, 18 Juli 2009.

Potts, J., dan T. Kastelle. 2010. Public Sector Innovation Research: What's Next?. Innovation: Management Policy \& Practice 12:122-137

Røste, Rannveig., dkk. 2005. Differences Between Public and Private Sector Innovation. European Union: Publin Report No. D9.

Sancoko, Bambang. 2010. Pengaruh Remunerasi terhadap Kualitas Pelayanan Publik. Jurnal IImu Administrasi dan Organisasi 17 (1): 43-51.

Santoso, Agus. 2014. Top 9 Kompetisi Inovasi Pelayanan Publik 2014. Majalah Layanan Publik, Edisi XLIX 2014.

Suwarno, Yogi. 2008. Inovasi di Sektor Publik. Jakarta: STIA-LAN Press.

Torugsa, N.A., dan A. Arundel. 2016. "Complexity of Innovation in the Public Sector: A Workgroup-Level Analysis of Related Factors and Outcomes". Public Management Review 18(3): 392-416.

United Nations. 2005. Innovations in the Public Sector: Compedium of Best Practices. New York: UNDESA.

2011. The Critical Role of Innovative Public Administration in Achieving the Millennium Development Goals. New York: UNDESA UNDESA.

2013. Good Practices and Innovations in Public Governance. New York:

Vigoda-Gadot, E. 2003a. Managing Collaboration in Public Administration: Governance, Businesses, and Citizens in the Service of Modern Society. Westport, Conn.: Praeger.

Yoshida, D.T., S. Sendjaya, G. Hirst, dan B. Cooper. 2014. "Does Servant Leadership Foster Creativity and Innovation? A Multi-Level Mediation Study of Identification and Prototypicality". Journal of Business Research 67 (7): 1395-1404. 